\title{
QUALITY IDENTIFICATION OF ENDEMIC Pagaralam Salak Fruit USINg EXPERT SySTEM
}

\author{
Buhori Muslim, Desi Puspita and Kasih Lestari \\ Department of Informatics Engineering, Sekolah Tinggi Teknologi Pagaralam, \\ Pagar Alam, Palembang, Sumatera Selatan, Indonesia
}

\begin{abstract}
Pagar Alam is a city with the aim of utilizing technology that is quite high, it can be seen from the public interest, with the ownership of plantations such as salak fruit. Based on the results of observations obtained if there is a problem at the time of harvest the community takes action directly to the agricultural service even though the obstacle is caused by a lack of understanding of plantations. So researchers consider that an expert system is needed to identify the quality of this fruit, the development of this expert system utilizes the advantages of the forward chaining method, forward chaining is a process that begins by describing the collection of data (facts) that are very accurate to conclusions (search) with the support of data starting from input information (if) preliminary to conclusions (then). The programming language used is PHP programming language, supported by MYSQL database. The stages of system development using the waterfall method are preceded by analysis, design, program code creation, testing and support or maintenance. The test is carried out to measure the validity of the system using the black box testing method.
\end{abstract}

\section{KEYWORDS}

Plantation, quality, fruit, forward chaining, database and waterfall.

\section{INTRODUCTION}

The development of Information and Communication Technology is very rapid [7], in which Technology and Information are inseparable in its development [11]. This world is entering the era of globalization where Information and Communication Technology plays an important role in human life. Humans need technology in every aspect of their lives to facilitate and expedite each activity. This situation is not only happening in developed countries, but also occurs in countries like Indonesia which will only experience development. The development of Information Technology in Indonesia is able to have a major influence on economic life. Efficiency in various fields, in particular the problem of time, energy and cost through speed and accuracy of information can be significantly increased, as well as means it has been able to make efficient use of space [8]. Pagaralam is an area that has its own special privileges in all respects, for example in the application of this technology requires technology activists to be resilient, and patient [9]. Technology has been applied to agriculture and fruits [4], fruit farmers in Pagaralam experienced difficulties when selecting quality fruit, so the idea came from researchers to create an expert system to identify fruit quality, especially salak (zalacca/thorny palm) [2,3] for farmers and Pagaralam endemic fruit traders. 


\section{METHOD}

The method is a technical carried out in the research process. While the research itself is defined as an effort in the field of science carried out to obtain facts and principles patiently, carefully systematically to realize the truth [7].

\subsection{Method of Collecting Data}

Data Collection Techniques conducted by researchers in this study, are as follows: Interviews, Observation, Documentation, Questionnaires and Literature studies.

\subsection{Systems Development Method}

In this study, researchers used a waterfall SDLC development model often called a linear sequential model or classic life style. This waterfall method is a software life cycle starting from analyzing, designing, coding, then testing and supporting [14].

\subsection{Theoretical Basis}

\subsubsection{Artificial Intelligence}

Artificial intelligence in English means Artificial Intelligence (AI). Intelligence is an adjective meaning intelligent, while Artificial means artificial. Artificial intelligence in question, refers to machines that are able to think, weigh the actions to be taken and are able to take decisions like humans do $[9,10]$. Artificial intelligence is a very important field of computer science now and in the future to realize intelligent computer systems. This field has developed very strongly in the last \pm 20 years as the need for intelligent devices in the industry and household [18].

\subsubsection{Knowledge}

Knowledge is something that is manifested in the language of one's soul and mind because of the reactions, touches and relationships with the environment and the natural surroundings.

\subsubsection{Semantic Network}

Semantic networks are commonly used knowledge to describe data and information that show the relationships between objects

\subsubsection{System}

The system is a set of interrelated (integrated) procedures for performing tasks together.

\subsubsection{Expert}

An expert is a person or individual who has special knowledge, understanding, experience and methods, and is able to apply it to solve various problems or to provide advice on his knowledge. An expert must be able to explain and learn new things related to the topic of the problem, if necessary must be able to rearrange the knowledge gained, and can solve the rules and determine relevance in accordance with expertise[7,9]. 


\subsubsection{Expert System}

This expert system method is part of artificial intelligence that combines the knowledge base with an inference system to duplicate an expert, this expert system is a system that adopts human knowledge into a computer (machine), so that the machine (computer) is able to solve problems as is commonly done by expert. It is expected that with this expert system, users can solve certain problems, without the help of experts in the field [18].

\subsubsection{Inference Engine}

The inference engine is the centre or brain of this expert system method, this part is the mechanism of thinking function and system reasoning patterns used by experts.

\subsubsection{Forward Chaining}

Forward Chaining is a method of inference engine to start reasoning of data from existing facts to a conclusion. Forward Chaining can also be interpreted as a decision making strategy that starts from the premise (facts) to the conclusions.

\subsubsection{Salak Fruit}

Fruit salak is a fruit arranged in bunches, located on the back of the leaf midrib or under the leaf midrib. The shape of the fruit varies depending on the type of salak fruit, the position or position of the fruit in bunches in the tree [3,4]. Generally the shape of the salak fruit is a round or inverted oval triangle with a diameter of up to $6 \mathrm{~cm}$ and a length of between $2.5-10 \mathrm{~cm}$. Fruit weight can reach 150 grams per fruit. The bottom of the fruit is tapered and at the end there is a pistil head. Fruit skin in the form of scales that are arranged like tiles $[3,6,17]$.

\subsubsection{MySql}

MySQL is a database management system software (database management system) or DBMS. In MySQL, a website is stored and processed. MySQL is quite popular, especially among web programmers who take shelter under the UNIX or LINUX operating system [10].

\subsubsection{Axure}

Axure is one of the design systems that specializes in designing browser-based applications, currently Axure is known as a standard for designing an application [7]. 


\subsubsection{System Design}

A. Use Case Diagram

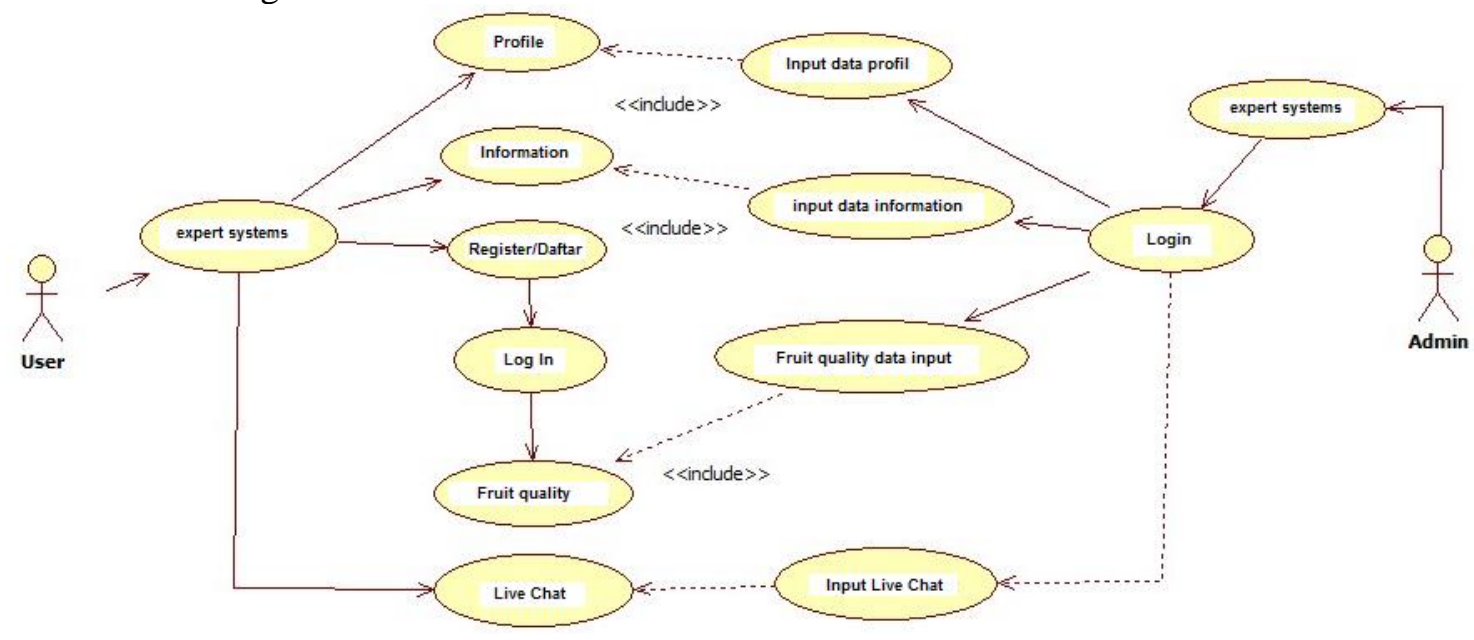

Figure 1. Use case diagram

Pagaralam's endemic salak fruit quality identification system has 2 actors namely user and admin, then the main menu is information, registers, fruit quality identification and live chat for users who will ask the manager as shown in Figure 1.

\section{B. Class Diagram}

Next after use case diagrams are class diagrams, consisting of user tables, criteria, quality, admin / officer tables, information, live chat and relations.

C. Story Board

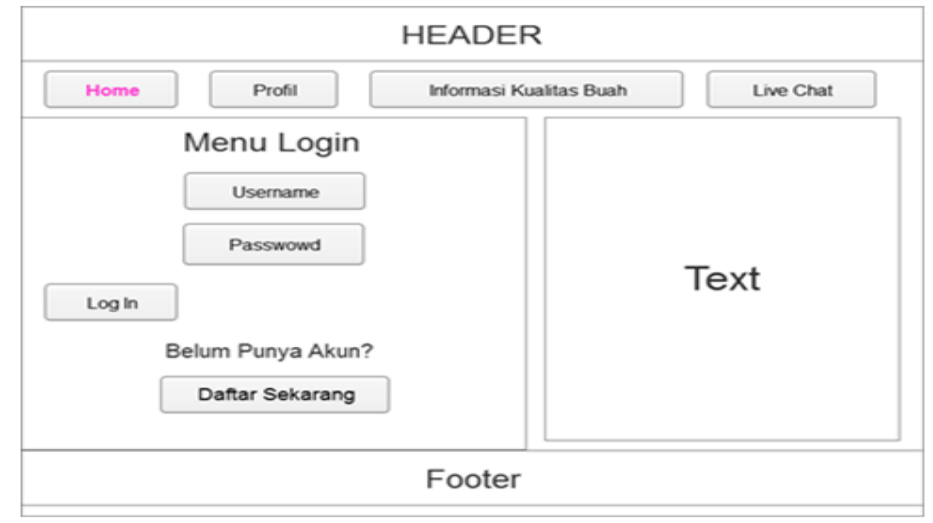

Figure 2. Story Board Home

The main menu consists of 4 menus namely: Home, Profile, Information on fruit quality and live chat. 
D. Menu Information on Fruit Quality

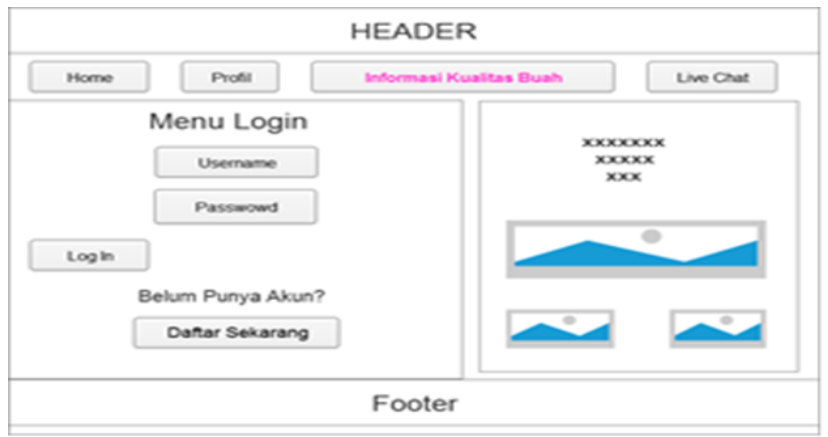

Figure 3. Fruit Quality Information Menu

Quality information menu, when the user will identify the fruit, he must register first, then after the user list will go to the next menu page criteria and rules.

E. Rule Text Page

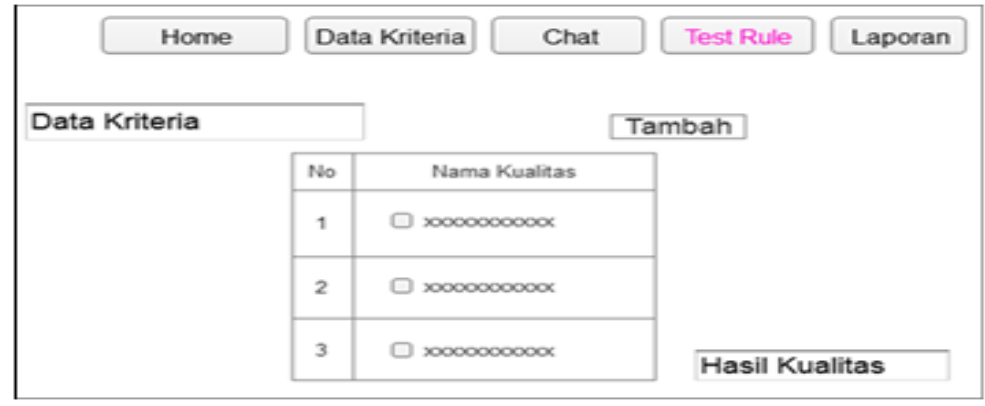

Figure 4. Rule Text Page

Figure 4 is a menu to try (test) the rules that have been determined (obtained) through research / data collection.

\section{F. Criteria Data Plan}

\begin{tabular}{|c|c|c|c|c|c|}
\hline Home & \multicolumn{2}{|c|}{ Data Kriteria } & Live Chat & Test Rule & Laporan \\
\hline \multirow[t]{5}{*}{ Data Kriteria } & & & & & Tambah \\
\hline & No & & lama Kualitas & \multicolumn{2}{|c|}{ Aksi } \\
\hline & 1 & $x \infty$ & வOX & Edit & Delete \\
\hline & 2 & $x>x$ & $x \times 0 x 0000000000 x$ & Edit & Delete \\
\hline & 3 & $x \times \infty$ & 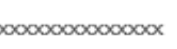 & Edit & Delete \\
\hline
\end{tabular}

Figure 5. Data criteria design

In the criteria data menu there is a menu for adding quality data and there are actions, edit actions and delets. 


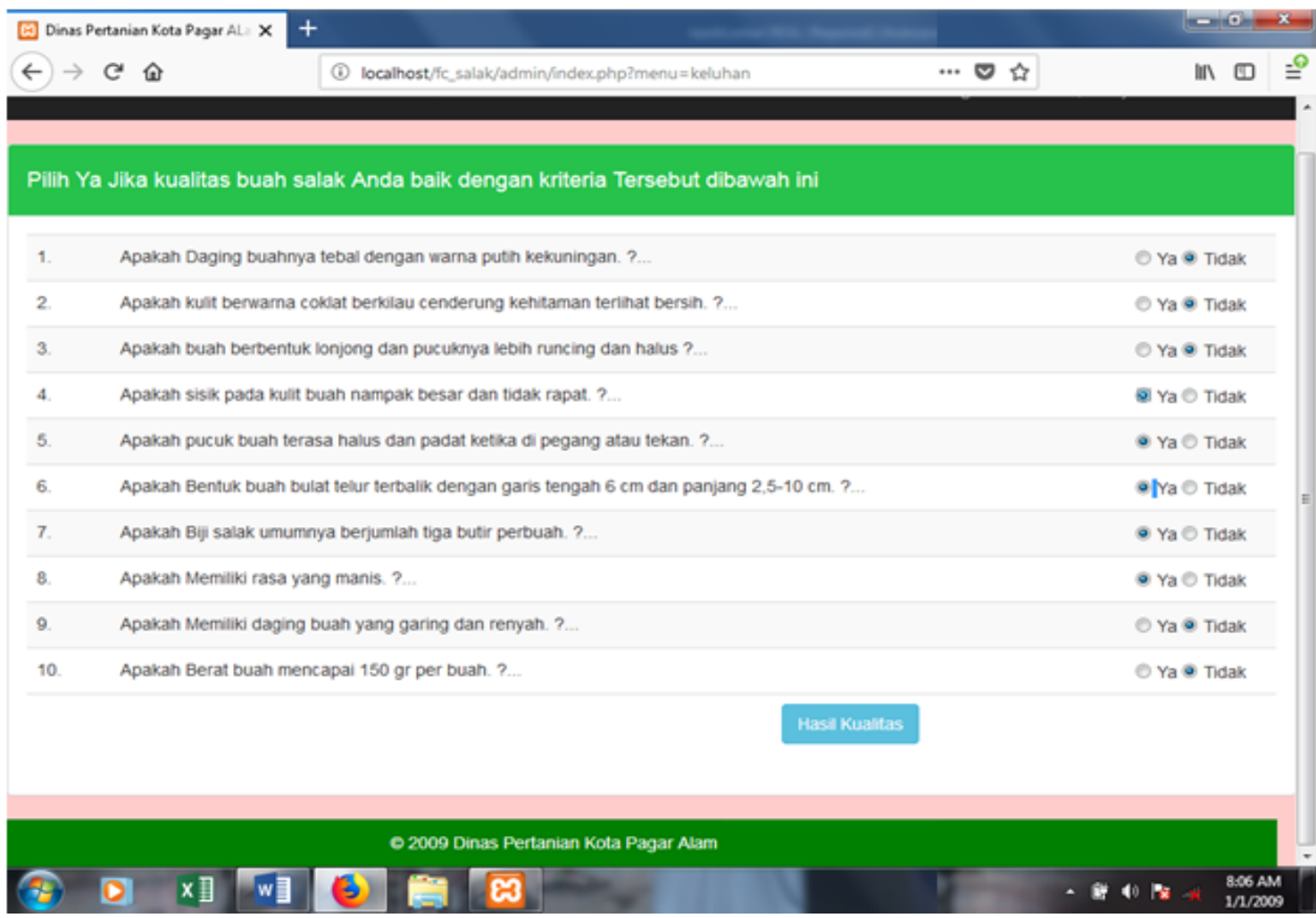

Figure 6. Output Data criteria

is a parameter that will be an input for the identification of the quality of salak fruit, which parameter is based on data obtained from experts, where all the characteristics that become input parameters for identification of this quality are based on the quality of existing or endemic fruits that are specifically present in the Pagaralam area, South Sumatra, Indonesia.

\section{G. Design Of Analysis Results}

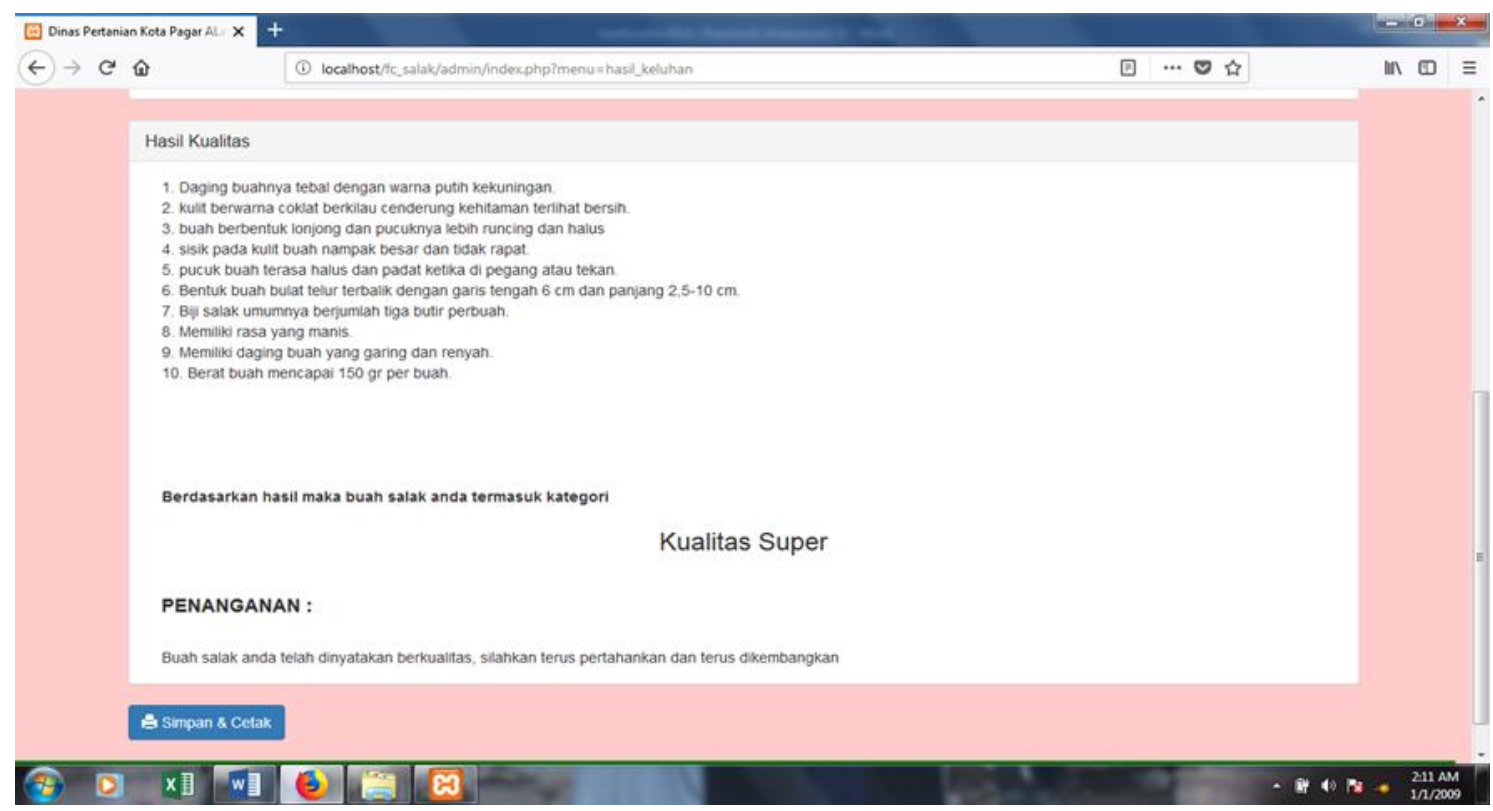

Figur 7. Output 
Figure 7 is the output of the results, or the conclusions obtained by the system after inputting the input parameters such as Figure 6, in this output the user will get information about the quality of the fruit and the conclusion if the fruit analyzed is really high quality, if there are deficiencies in this output also has been equipped with appropriate handling methods without having to meet with experts directly.

\section{Conclusions}

From the results of the analysis and discussion conducted by the researcher in the previous section, the researcher draws the following conclusions:

a. This expert system can provide information and diagnostics to determine the quality of salak fruit so that people know better the quality of salak fruit.

b. This expert system method can help the user to make it easier to obtain information about the quality of salak fruit according to the criteria experienced according to the diagnosis made.

c. This expert system can also be used as a medium for the application of the intelligence of an expert or expert in analyzing the quality of salak fruit in accordance with the criteria.

\section{ACKNOWLEDGEMENTS}

Special thanks to my girls Aulia \& Innara love u bab. Thanks to LPPM STT Pagaralam and organizer of the AIRCC journal

\section{REFERENCES}

[1] Agung, M. (2016). Pemrograman PHP dan MySQL untuk Pemula. Yogyakarta: C.V Andi Offset.

[2] Anarsis, W. (1996). Agribisnis Komoditas Salak. Jakarta: Bumi Aksara.

[3] Drs. Harsoyo Purnomo, M. (2000). Budi Daya Buah Salak. Semarang: CV.Aneka Ilmu.

[4] Jeperson Hutahaean, Y., (2015). Expert system untuk mendiagnosa penyakit tanaman buah berbasis web. Jurnal APTEK.

[5] Jogiyanto HM, M. (2008). Sistem Tenologi Informasi. Yogyakarta: Andi Yogyakarta.

[6] M.Shalahuddin, R. A. (2018). Rekayasa Perangkat Lunak Terstruktur dan Berorientasi Objek. Bandung: Informatika Bandung.

[7] Muslim, B. (2017). Pengantar Teknologi informasi Teknik Informatika. Yogyakarta: C.V BUDI UTAMA.

[8] Muslim, B. (2018). Analisis system informasi (SI) terintegrasi di Perguruan Tinggi (PT) (Studi Kasus: STT Pagaralam). Jurnal Teknologi Informasi MURA, Vol 10. Page 83-91.

[9] Muslim, B (2017). Sistem Pakar Diagnosa Awal Penyakit Ginjal Berbasis Web Menggunakan PHP Dan MySQL (Studi Kasus: RSUD Besemah Kota Pagar Alam). JURNAL BETRIK, LPPM STTP, Vol 12, Pp 115-122. 
[10] Muslim, B. (2019). Rancang Bangun Website Madrasah Al-Azhar Kota Pagar Alam. BETRIK, LPPM. Vol. 17, pp 94-103

[11] Pramudita Eka Hananto, P. S. (2012). sistem pakar diagnosis penyakit tanaman cengkih dengan metode inferensi forward chaining. Journal of Informatics and Technology.

[12] Pratama, I. P. (2014). Sistem Informasi dan Implementasinya. Bandung: Informatika Bandung.

[13] Raharjo, B. (2016). Modul Pemrograman Web (HTML, PHP dan MySQL). Bandung: Modula.

[14] Rosa A.S, M. (2016). Rekayasa Perangkat Lunak Terstruktur dan Berorientasi Objek. Bandung: Informatika.

[15] Rosa A.S, M. S. (2016). Rekayasa Perangkat Lunak Berorientasi Objek. Bandung: Informatika.

[16] Rosa, \& Shalahuddin, M. (2018). Rekayasa Perangkat Lunak. Bandung: Informatika.

[17] Tjahjadi, I. N. (1989). Bertanam Salak. Yogyakarta: Penerbit Kanisius.

[18] Zulfian Azmi, S. d. (2017). Penghantar Sistem Pakar dan Metode. Jakarta: Mitra Wacana Media.

\begin{tabular}{ll} 
Authors & \\
\multicolumn{2}{l}{ Short Biography } \\
Name & $:$ Buhori Muslim \\
NIDN & $:$ 0204127903 \\
Affiliation & $:$ STT Pagaralam, Indonesia \\
Phone & $:+06281329934745$ \\
& \\
Name & $:$ Desi Puspita \\
NIDN & $:$ O202028601 \\
Affiliation & $:$ STT Pagaralam, Indonesia \\
Phone & $:$ +6285279011390 \\
& \\
Name & $:$ Kasih Lestari \\
Affiliation & $:$ STT Pagaralam
\end{tabular}

